\title{
MENCIPTAKAN ITIKAD BAIK YANG BERKEADILAN DALAM KONTRAK ASURANSI JIWA
}

\author{
Zahry Vandawati Chumaida \\ zahr_vandawati@yahoo.co.id \\ Fakultas Hukum Universitas Airlangga
}

\begin{abstract}
An insured who bind themselves to the insurer to protect his life by taking life insurance, of course, will conduct the closing of the contract of insurance agreements. To close this insurance contract the insured is deemed very essential to peruse the terms and conditions and the rights and obligations that will he get. In many cases it is turned to be extremely detrimental to the insured party when related to the contract of insurance. This is due to a lack of good faith on the part of the insurer to pay insurance claim filed by the insured or beneficiary. Instead, the insured is required to execute an agreement in good faith even at the beginning of the insurance contract the insured has been burdened insurance for acting in good faith.
\end{abstract}

Keywords: contract, good faith, life insurance.

\begin{abstract}
Abstrak
Seorang tertanggung yang mengikatkan diri kepada penanggung untuk melindungi jiwanya dengan ikut asuransi jiwa, tentunya akan melakukan kontrak penutupan perjanjian asuransi. Dalam melakukan penutupan perjanjian asuransi ini dipandang sangat perlu sekali tertanggung membaca dengan teliti syarat dan ketentuan serta hak dan kewajiban yang akan dia dapatkan. Banyak kasus yang terjadi yang ternyata amat sangat merugikan pihaks tertanggung terkait dengan kontrak perjanjian asuransi.Hal ini diakibatkan kurangnya itikad baik dari pihak penanggung untuk menbayar klaim asuransi yang diajukan oleh pihak tertanggung atau ahli waris. Sebaliknya pihak tertanggung diwajibkan untuk beritikad baik dalam melakukan perjanjian asuransi bahkan diawal kontrak asuransipun tertanggung sudah dibebani untuk beritikad baik.
\end{abstract}

Kata kunci: kontrak, itikad baik, asuransi jiwa. 


\section{Pendahuluan}

Hidup manusia tidak pernah lepas dari bahaya, beberapa macam bahaya yang mengancam kehidupan manusia disebabkan oleh peristiwa yang timbul secara mendadak tanpa diduga sebelumnya seperti meninggal dunia, menderita suatu penyakit, terjadi kecelakaan ataupun sebab yang lainnya. Melihat peristiwa tersebut yang terjadi pada orang lain maka kita dapat menyadari apabila peristiwa tersebut terjadi pada diri kita. Alasan tersebut mendorong orang untuk mencari suatu perlindungan atau jaminan rasa aman terhadap persiapan masa depan yang lebih baik dan pasti. Asuransi jiwa sangat penting untuk melindungi jiwa dari risiko hidup yang tidak pasti, melindungi kebutuhan hidup serta untuk mengurangi beban bagi keluarga yang ditinggalkannya.

Prinsip itikad baik (Utmost Good Faith) ${ }^{1}$ menjadi asas yang paling penting dalam hukum kontrak. ${ }^{2}$ Prinsip itikad baik menjadi salah satu instrument hukum untuk membatasi kebebasan berkontrak dan kekuatan mengikatnya perjanjian. ${ }^{3}$ Prinsip itikad baik yang terdapat dalam Pasal 1338 ayat (3) KUH Perdata seharusnya diberlakukan bukan hanya pada saat ditandatanganinya dan dilaksanakan kontrak, tetapi juga pada saat sebelum ditandatanganinya kontrak. ${ }^{4}$ Secara umum, itikad baik dapat diartikan bahwa masing-masing pihak dalam suatu perjanjian yang akan disepakati, menurut hukum mempunyai kewajiban untuk memberikan keterangan atau informasi yang selengkap-lengkapnya, yang dapat mempengaruhi keputusan pihak yang lain untuk memasuki perjanjian atau tidak, baik keterangan yang demikian itu diminta atau tidak. ${ }^{5}$ Prinsip dan ketentuan tersebut berlaku pula dalam setiap kontrak asuransi. Menurut prinsip ini, setiap kontrak asuransi harus ditandatangani oleh kedua belah pihak yaitu perusahaan asuransi selaku penanggung dan pemegang polis selaku tertanggung. Prinsip tersebut mencerminkan hak dan kewajiban masing-masing pihak.

Sebagai refleksi dari prinsip itikad baik yang diatur dalam pasal 1338 ayat (3) BW tersebut, untuk semua kontrak asuransi secara khusus diatur pada Pasal $251 \mathrm{WvK}$ sebagai les spesialis dari itikad baik berdasarkan ketentuan hukum perdata. ${ }^{6}$ Tujuan dari pasal 251 KUHD adalah melindungi penanggung atau membebaskannya dari risiko yang tidak secara adil diperalihkan kepadanya, sehingga dalam pasal ini tidak menjadi pertimbangan apakah pada tertanggung terdapat itikad jahat atau itikad baik.Ketentuan Pasal 251 WvK mempunyai arti

1 Prinsip yang terkandung dalam Pasal $251 \mathrm{WvK}$ pada dasarnya merupakan prinsip uberrima fides atau uberrimae fidei yang dalam bahasa Inggris dipergunakan istilah the principle of utmost good faith.

2 Ridwan Khairandy, Itikad Baik Dalam Kebebasan Berkontrak, Universitas Indonesia Fakultas Hukum Pascasarjana, 2003, h.128.

3 Ibid., h. 3.

4 Di dalam Pasal 1338 (3) BW dikatakan bahwa setiap kontrak harus dilaksanakan dengan itikad baik (zij moten te goeder trouw worden ten vitvoer verklaart). Ketentuan ini kemudian dilanjutkan dengan Pasal 1339 BW yang menyatakan bahwa kontrak tidak hanya mengikat terhadap yang apa secara tegas dinyatakan di dalamnya, tetapi juga kepada segala sesuatu yang bersifat kontrak yang diharuskan oleh kepatutan, kebiasaan, dan undang-undang (overeenkomsten verbinden niet allen tot datgene hetwelk uitdrukkelijk bij dezelve bepaald is, maar ook tot al hetgeen dat, naar den aard van dezelve oveenkomsten, door de bilijkheid, het gebruik, of de wet, word gevorded).

5 Ibid, h. 4.

6 Sri Rejeki Hartono, Asuransi dan Hukum Asuransi, Semarang: IKIP Semarang Press, h. 103. 
penting setelah terjadi peristiwa tidak pasti (evenemen) yang menimbulkan kerugian, sehingga menjadi alasan bagi penanggung untuk menghindarkan diri dari kewajiban membayar ganti kerugian. Namun, bagi tertanggung yang jujur merupakan kekecewaan karena tidak mendapat ganti kerugian dengan alasan asuransi batal, padahal dia telah berusaha untuk mengadakan asuransi dengan maksud untuk menghindari risiko. Banyak penanggung mengklaim bahwa tertanggung tidak melaksanakan itikad baik (breach of utmost good faith) sehingga klaim asuransi yang diajukan ditolak oleh perusahaan asuransi.Dalam banyak kasus, seringkali niat baik tertanggung untuk melakukan sesuatu berkaitan dengan klaim asuransi menjadi bumerang karena ternyata tindakan itu melanggar ketentuan kontrak. Di sisi lain tertanggung tidak mengetahui bahwa niat baik itu ternyata menjadi tidak baik, yang pada akhirnya menjadi grey area timbulnya konflik dari tuntutan ganti kerugian.

Perlindungan yang diberikan oleh pembentuk undang-undang kepada penanggung melalui Pasal 251 KUHD terlalu berlebihan. Utmoust good faith seolah-olah hanya menjadi kewajiban si tertanggung, dimana si penanggung tidak perlu menunjukkan itikad baik kepada tertanggung. Oleh sebab itu tidak mustahil pula jika ketentuan pasal tersebut dijadikan senjata oleh penanggung untuk menghantam tertanggung yang jujur atau beritikad baik, karena penanggung tidak berkewajiban untuk menegur atau memberi peringatan guna menghindarkan hal-hal penyebab kebatalan. Ketentuan tersebut dirasakan tidak adil bagi tertanggung karena terlalu melindungi penanggung untuk menghindarkan diri dari tanggung jawab membayar klaim ganti rugi kepada tertanggung.

\section{Itikad Baik Dalam Perjanjian Asuransi Yang Berkeadilan}

Itikad baik para pihak dalam melakukan perjanjian harus memperhatikan kepatutan. Setiap perjanjian harus didasarkan pada pretium iustum yang mengacu kepada reason dan equity yang mensyaratkan adanya keseimbangan antara kerugian dan keuntungan bagi kedua belah pihak dalam perjanjian. Hal ini sejalan dengan tujuan hukum yang notabene berupaya merealisasikan keadilan. Itikad baik tak lain menjadi pedoman bahwa isi perjanjian harus memuat nilai-nilai keadilan. ${ }^{7}$

Dalam kontrak atau perjanjian asuransi biasanya dibuat oleh pihak penanggung untuk tertanggung yang pada umumnya memiliki pengetahuan asuransi yang terbatas, yang membuat tertanggung menjadi pihak yang lemah. Faktor penentuan bagi keabsahan atau keadilan pertukaran pada perjanjian adalah kesetaraan para pihak. Keseimbangan dalam kontrak asuransi bukan dicari dalam situasi dan kondisi faktual apakah tujuan perjanjian benar seimbang atau tidak, namun lebih terfokus pada pertanyaan apakah perjanjian terbentuk dalam kondisi yang seimbang dan atau apakah perjanjian dari segi substansi atau maksud dan tujuan serta pelaksanaannya dapat memunculkan kondisi ketidakseimbangan. Perjanjian memiliki sejumlah aspek yaitu perbuatan para pihak, isi perjanjian dan pelaksanaan dari apa yang telah disepakati.

\footnotetext{
7 Ridwan Khairandy, Op.Cit., h.3.
} 
Perbuatan para pihak dalam kontrak asuransi merupakan perbuatan hukum yang ditujukan pada suatu akibat hukum yaitu menyangkut pernyataan kehendak dan kewenangan bertindak untuk menciptakan, mengubah dan mengakhiri suatu hubungan hukum tertentu. Isi kontrak atau perjanjian harus mengandung asas kebebasan berkontrak sepanjang tidak bertentangan dengan undang-undang dan kesusilaan yang baik dan ketertiban umum. ${ }^{8}$

Itikad baik atau utmost good faith dalam perjanjian asuransi sangat penting karena menyangkut hak dan kewajiban tertanggung serta penanggung. Itikad baik menjadi asas yang paling penting dalam hukum perjanjian. ${ }^{9}$ Untuk itu dalam perjanjian asuransi juga disebut sebagai contract of utmost good faith.Itikad baik ini biasanya dipasangkan dengan fair dealing. ${ }^{10}$ Seperti yang telah disebutkan di atas bahwa definisi itikad baik dalam kenyataannya sangat sulit menemukan pengertian dan definisi yang jelas tentang itikad baik.Hal ini dapat dipahami karena pengaturan hukum perjanjian sangat minim, bahkan di negara-negara civil law yang memasukkan ketentuan itikad baik ke BW hanya mengatur sedikit saja. ${ }^{11}$ Ada yang mendefinisikan utmost good faith sebagai Utmost good faith means a positive duty to voluntarily disclose, accurately and fully, all facts material to the risk being proposed, whether asked for them or not. ${ }^{12}$

Itikad baik atau utmost good faith merupakan suatu dasar pokok dan kepercayaan yang menjadi landasan setiap perjanjian termasuk perjanjian asuransi, dan pada dasarnya hukum tidak melindungi pihak yang beritikad buruk. Sebagai refleksi dari asas itikad baik yang diatur dalam Pasal 1338 ayat (3) BW, untuk semua perjanjian asuransi secara khusus diatur pada Pasal 251 KUHD. Asas yang terkandung dalam Pasal 251 KUHD pada dasarnya merupakan asas uberrima fides atau uberrimae fidei yang dalam bahasa Inggris dipergunakan istilah the principle of utmost good faith.Asas itikad baik yang sempurna ini adalah merupakan lex spesialis dari itikad baik berdasarkan ketentuan hukum perdata. ${ }^{13}$ Dari Pasal 251 KUHD di atas dapat diketahui bahwa dibedakan dua hal yaitu: a) Memberikan keterangan/informasi yang keliru atau tidak benar; dan b) Tidak memberikan keterangan/informasi mengenai keadaan-keadaan yang diketahui. ${ }^{14}$ Secara umum, itikad baik dapat diartikan bahwa masingmasing pihak dalam suatu perjanjian yang akan disepakati, menurut hukum mempunyai kewajiban untuk memberikan keterangan atau informasi yang selengkap-lengkapnya, yang dapat mempengaruhi keputusan pihak yang lain untuk memasuki perjanjian atau tidak, baik keterangan yang demikian itu diminta atau tidak. ${ }^{15}$ Kewajiban untuk memberikan fakta-fakta

8 Herlian Budiono, Asas keseimbangan Bagi Hukum Perjanjian Indonesia Hukum Perjanjian Berlandaskan Asas- Asas Wigati Indonesia, Bandung: Citra Aditya Bakti, 2008, h. 332-338.

9 Ridwan Khairandy, Op.Cit., h.128.

10 Ibid, h. 130.

11 Ibid, h. 7.

12 Basic Insurance Concept and Principles, Singapore: Singapore College of Insurance Limited, 2002, h. 41.

13 Sri Rejeki Hartono, Op.Cit., h. 103.

14 Ibid, h. 104.

15 Ibid. 
penting tersebut berlaku: a) Sejak perjanjian asuransi dibicarakan sampai perjanjian asuransi selesai dibuat, yaitu pada saat kedua belah pihak menyetujui kontrak tersebut; b) Pada saat perpanjangan kontrak asuransi; c) Pada saat terjadinya perubahan pada kontrak asuransi dan mengenai hal-hal yang ada kaitannya dengan perubahan-perubahan itu. ${ }^{16}$

Salah satu senjata yang sering digunakan oleh penanggung untuk melindungi dirinya untuk tidak membayar klaim asuransi adalah ketentuan Pasal 251 KUHD. Tujuan dari Pasal 251 KUHD adalah melindungi penanggung atau membebaskannya dari risiko yang tidak secara adil diperalihkan kepadanya, sehingga dalam pasal ini tidak menjadi pertimbangan apakah pada penanggung terdapat itikad jahat atau itikad baik. ${ }^{17}$

Apabila dicermati secara gramatikal Pasal 251 KUHD hanya menitik beratkan pada tertanggung yang harus beritikad baik, sedangkan penanggung dalam hal ini perusahaan asuransi tidak disebutkan didalamnya.Sehingga jelas pasal ini sangat timpang dan terdapat kelemahan serta tidak ada posisi yang seimbang antara tertanggung dan penanggung.Dalam membaca sebuah pasal sebenarnya Pasal 251 KUHD ini tidak boleh hanya ditekankan tertanggung saja yang diwajibkan untuk beritikad baik, namun penanggung juga wajib memiliki itikad baik.Untuk menetapkan isi perjanjian perlu diadakan penafsiran apabila timbul perbedaan pengertian, sehingga jelas diketahui maksud para pihak ketika mengadakan perjanjian. A. Pitlo mengatakan ada berbagai cara menafsirkan, yaitu gramatikal ${ }^{18}$, sistematis ${ }^{19}$, historis ${ }^{20}$, namun tidak berarti hanya satu atau lebih yang dipergunakan atau mendahulukan yang satu dari yang lain dalam menafsirkan undang-undang tetapi semua secara bersama-sama.

Kewajiban untuk memberikan fakta-fakta penting tersebut berlaku: 1) Sejak perjanjian asuransi mulai dibicarakan sampai perjanjian asuransi selesai dibuat, yaitu pada saat penanggung menyetujui perjanjian tersebut; 2) Pada saat perpanjangan perjanjian asuransi; 3) Pada saat terjadinya perubahan pada perjanjian asuransi dan mengenai hal-hal yang ada kaitannya dengan perubahan-perubahan itu; 4) Tidak menyembunyikan keterangan yang jelas dan benar yang dibutuhkan masing-masing pihak.

Apabila perjanjian asuransi di ibaratkan suatu bangunan, prinsip itikad baik adalah fondasinya, artinya apabila fondasi tersebut tidak dikontruksi dengan baik, dikhawatirkan bangunan perjanjian asuransi akan ambruk atau gagal mencapai tujuannya, karena beberapa kasus asuransi masalah itikad baik sering menjadi pokok permasalahan. Prinsip itikad baik ini mengandung pengertian kedua belah pihak, yaitu tertanggung dan penanggung secara timbal balik harus mendasari kesepakatan atau perjanjian asuransi dengan itikad sangat baik, artinya

16 <http://ryaniskandar.wordpress.com/Prinsip -prinsip Dasar Asuransi>, diakses pada tanggal 3 Juli 2013.

17 Emmy Pangaribuan Simanjuntak, Op.Cit., h. 47.

18 Penafsiran gramatikal adalah menangkap arti suatu naskah menurut bunyi kata-katanya.

19 Penafsiran sistematis adalah undang-undang harus dibaca secara keseluruhannya tidak boleh mengeluarkan suatu ketentuan lepas dari keseluruhannya tetapi harus meninjau dalam hubungannya dengan ketentuan sejenis.

20 Penafsiran historis dilakukan sejarah pembuatannya sehingga memperoleh makna yang tersembunyi di belakang kata-kata. 
tidak menyembunyikan keterangan yang jelas dan benar yang dibutuhkan masing-masing pihak. Kata "sangat" yang tercantum dalam prinsip itikad baik terkadang cenderung ditujukan kepada tertanggung, dengan pertimbangan tertanggung yang akan mengalihkan risiko kepada penanggung atau perusahaan asuransi mengetahui segala sesuatunya tentang objek yang akan diasuransi sedangkan penanggung tidak mengetahuinya, apabila tertanggung tidak memberitahukan keterangan tentang objek asuransi kepada penanggung. Penanggung dapat melakukan survey atas risiko terhadap ojek asuransi untuk asuransi kerugian, sedangkan untuk asuransi jiwa penanggung berhak mendapatkan data kesehatan dan latar belakang pekerjaan dari tertanggung apakah memiliki penyakit yang dapat menyebabkan terjadinya kematian ataukah tingkat.pekerjaan yang memiliki risiko tinggi untuk dapat terjadinya kematian.

Semua yang diinginkan untuk diketahui penanggung, di dalam praktek sudah disebutkan dalam formulir polis untuk diisi oleh tertanggung, namun tidak berarti bahwa hanya pertanyaan-pertanyaan yang ditempatkan dalam formulir itu yang harus dijawab tertanggung. Tertanggung harus memberitahukan keterangan-keterangan yang benar dan jelas terutama terkait dengan bahaya-bahaya yang mengancam jiwa yang diasuransikan agar diketahui besar kecilnya risiko yang ditanggung oleh penanggung yang berhubungan dengan besar kecilnya premi yang akan ditentukan. Namun di pihak lain ketentuan Pasal 251 KUHD tersebut dirasakan terlalu memberatkan tertanggung disebabkan karena: a) Ancaman yang sama berupa batalnya asuransi terhadap tertanggung yang beritikad baik; b) Tidak diberikan kesempatan memperbaiki kekeliruannya bagi tertanggung yang keliru dalam memberikan keterangan. ${ }^{21}$

Pada prinsip itikad baik tertanggung pada saat melakukan mengajukan form aplikasi penutupan asuransi berkewajiban memberitahukan secara jelas dan teliti mengenai segala fakta penting yang berkaitan dengan dirinya atau obyek yang diasuransikan serta tidak berusaha dengan sengaja untuk mengambil untung dari penanggung. Dengan kata lain tertanggung tidak menyembunyikan sesuatu fakta yang dapat dikategorikan sebagai menutup-nutupi kelemahan dan kekurangan atas diri atau obyek yang dipertanggungkan, mengingat hal ini berkaitan erat dengan resiko, penetapan pembayaran premi serta kewajiban penanggung jika terjadi kerugian yang diderita oleh tertanggung. Prinsip ini jika dicermati juga sesuai dengan implementasi Pasal 1320 dan Pasal 1338 BW, bahwa perjanjian yang dibuat harus berdasarkan atas dasar sebab yang dibolehkan serta perjanjian harus dilaksanakan dengan itikad baik.

Dalam perjanjian asuransi ketentuan tentang kewajiban tertanggung untuk menyampaikan mengenai obyek yang diasuransikan dengan sesungguhnya dan sejujurnya, seperti yang dimaksudkan dalam Pasal 251 KUHD. Kewajiban pemberitahuan tersebut penting bagi penanggung, agar penanggung dapat memberikan penilaian mengenai besar kecilnya resiko yang dihadapi dan menjadi faktor dalam penentuan premi serta menjadi bahan pertimbangan dalam menerima atau menolak perjanjian asuransi. Ketentuan tersebut tidak

21 M. Suparman Sastrawidjaja, Op. Cit., h.13. 
membedakan antara tertanggung yang beritikad buruk dengan tertanggung yang beritikad baik. Menurut ketentuan Pasal 251 KUHD, apabila tertanggung memberitahukan hal yang tidak yang sebenarnya, memberitahukan hal yang keliru dan tidak sejelas-jelasnya maka, apabila hal ini terjadi, sanksi yang diberikan adalah mengakibatkan batalnya perjanjian asuransi, jelas hal ini sangat memberatkan tertanggung yang beritikad baik.

Pemberlakuan prinsip itikad baik dari tertanggung boleh dikatakan sudah kembali bergeser kearah apa yang sudah dikenal umum dalam Pasal 1338 (3) BW, yakni prinsip itikad baik kedua belah pihak dalam perjanjian. Itikad baik yang diatur secara khusus dalam Pasal 251 KUHD dipandang sudah tidak pantas diberlakukan lagi.Untuk itulah penulis mengusulkan pada disertasi ini untuk merekontruksi kembali Pasal 251 KUHD sehingga terjadi keseimbangan terhadap para pihak dalam melakukan perjanjian asuransi.Hal ini sebenarnya juga ditegaskan dalam usulan Rancangan Undang-Undang Perjanjian Asuransi yang sebenarnya sudah jauhjauh hari dibuat, namun pada saat ini RUU tersebut belum juga disetujui oleh anggota Dewan Perwakilan Rakyat. Penulis mengusulkan untuk merekontruksi ulang Pasal 251 KUHD tersebut dengan pertimbangan bahwa selama ini hukum perjanjian asuransi belum pernah disesuaikan dengan perkembangan dunia dari lembaga yang berhakikat internasional. Selama ini hukum tentang perjanjian asuransi yang ada tidak dapat dipertahankan lebih lama lagi dan harus segera direvisi total untuk penyesuaian dengan Pancasila dan Undang-Undang dasar 1945 serta perkembangan hukum baru di mancanegara. Mempertimbangkan hal-hal tersebut maka dipandang perlu untuk menetapkan undang-undang tentang Perjanjian Asuransi yang baru untuk menggantikan Wetboek van Koopenhandel Boek 1, titel 9 dan 10, Boek 2 Titel 9 dan $10 . .^{22}$

Dalam definisi perjanjian asuransi di NBW pasal 7.17.1.1.1 para pihak dinamakan penanggung (verzekeraar) dan pengambil asuransi (verzekeringnemer, applicant, proposer). Pengambil asuransi adalah mitra penanggung dalam penutupan perjanjian asuransi. Dalam pada itu yang dapat mengambil asuransi dapat tertanggung sendiri, maupun pihak lain yang mengambil asuransi yang bersangkutan untuk kepentingan pihak ketiga. Yang dikenakan kewajiban pemberian keterangan selengkapnya tentang risiko yang ditawarkan untuk ditutup (dijamin) oleh penanggung (medelingsplicht Pasal 251 KUHD) yang diketahui oleh si pengambil asuransi, atau yang patut diketahuinya, bahwa keputusan penanggung apakah ia akan memberi asuransi yang diminta atau tidak, dan jika memberi dengan persyaratan apa, digantungkan pada fakta yang bersangkutan. ${ }^{23}$

Rumusan ini ternyata sesuai dengan rekomendasi The Law Commision Inggris di bawah pimpinan Lord Kerr, $1980,{ }^{24}$ yang pada akhirnya telah memperoleh tempat dalam legislasi hukum perjanjian asuransi baru Australia (1984), tetapi tidak untuk di Inggris. Salah

22 H.Gunanto, Naskah Akademik Peraturan Perundang-undangan tentang Perjanjian Asuransi, Badan Pembinaan Hukum Nasional, Departemen Kehakiman, 1993/1994, h.77-78.

23 Ibid, h.27.

24 Ibid, h. 28, Disampaikan pada parlemen Inggris oleh Menteri Kehakiman (Lord High Hancellor) atas instruksi Ratu, Oktober 1980, diterbitkan oleh Her Majesty’s Stationery Office, London. 
satu isinya juga mengkaji apakah tertanggung juga perlu dibebani kewajiban pemberitahuan tersebut?Tidak dapatkah dalam asuransi dianut bahwa para pihak, penanggung harus waspada sendiri.Hal ini berlaku untuk tertanggung individual yang dapat dibebaskan dari kewajiban tersebut.Jadi penanggung apabila menganggap risiko tersebut penting baginya, maka penanggung harus mengajukan pertanyaan khusus mengenai obyek asuransi, tanpa pertanyaan demikian, maka si tertanggung bebas dari kewajiban memberi keterangan.Hukum baru di Netherland telah mengatur kewajiban pemberian keterangan lengkap tentang risiko yang hendak diasuransikan sesuai dengan rekomendasi Lord Kerr. ${ }^{25}$

Dalam rangka mencapai keadilan dalam membuat kontrak perjanjian asuransi maka perlu diperhatikan asas-asas perjanjian dalam yang dibuat untuk mengatur para pihak yaitu: 1) Asas konsensualisme; 2) Asas kebebasan berkontrak; 3) Asas Pacta Sunservanda; 4) Asas Itikad Baik; 5) Asas perlindungan; 6) Asas keterbukaan. Asas perlindungan dan keterbukaan perlu ditambahkan selain ke empat asas umum perjanjian. Kedua asas tersebut perlu dimasukkan dalam pembuatan kontrak perjanjian asuransi dengan pertimbangan bahwa asas perlindungan hukum terhadap para pihak dalam perjanjian asuransi belum terpenuhi. Asas perlindungan mengandung pengertian kesadaran akan fungsi masing-masing pihak dalam perjanjian asuransi, yaitu tertanggung maupun penanggung serta tanggung jawab masing- masing pihak untuk memenuhi berbagai kewajiban guna memperoleh haknya. Penanggung dan tertanggung dapat memperoleh perlindungan hukum apabila mengalami perlakuan kesewenang-wenangan yang menimbulkan kerugian baginya. Perlindungan hukum tidak hanya diberikan kepada tertanggung, yang selama ini dianggap sebagai pihak yang lemah, mengingat keberadaan tertanggung senantiasa terabaikan pada saat pembuatan perjanjian asuransi. Pihak penanggung selama ini dianggap sebagai pihak yang kuat karena mengendalikan proses terjadinya perjanjian. Apabila haknya dilanggar maka para pihak boleh menuntut haknya.

Asas keterbukaan dalam pembuatan perjanjian asuransi juga perlu dicantumkan, mengingat bahwa dalam praktek perjanjian asuransi seringkali terjadi adanya ketidakjelasan informasi atau informasi yang sengaja disembunyikan. Informasi diawal sebelum terjadinya penutupan perjanjian asuransi seringkali diingkari oleh pihak tertanggung, begitu juga informasi yang dituangkan dalam perjanjian asuransi seringkali terjadi ketidakjelasan sehingga dapat merugikan pihak tertanggung. Asas keterbukaan mengandung pengertian adanya informasi yang benar yang dapat diakses sehingga memberikan kejelasan bagi para pihak untuk terwujudnya transparansi dalam perjanjian asuransi. Hal ini memungkinkan para pihak dapat melaksanakan kewajiban secara optimal untuk memperoleh haknya sehingga dapat dihindari adanya beberapa kekurangan dan penyimpangan.

Kedua asas tersebut di atas (asas perlindungan dan keterbukaan) dikemukakan sebagai asas yang seharusnya ada dalam perjanjian asuransi selanjutnya dengan pertimbanganpertimbangan bahwa secara teoritis kedua asas tersebut merupakan penjabaran dari teori

\footnotetext{
25 Ibid, h. 28.
} 
keadilan dan asas itikad baik, kepatutan, dan keseimbangan dalam perjanjian asuransi. Apabila kedua asas tersebut dicantumkan dalam perjanjian asuransi, maka akan terbentuk perjanjian asuransi jiwa yang berkeadilan yang diinginkan oleh para pihak, yaitu terjadi keseimbangan hak dan kewajiban.

\section{Perlindungan Hukum Tertanggung Terkait dengan Tanggung Jawab Penanggung}

Beberapa pasal dalam KUHD yang dapat digunakan untuk melindungi tertanggung. Pasal 254 KUHD melarang para pihak dalam perjanjian, baik pada waktu diadakannya perjanjian maupun selama berlangsungnya perjanjian asuransi menyatakan melepaskan hal-hal yang oleh ketentuan undang-undang diharuskan. Hal ini untuk mencegah supaya perjanjian asuransi tidak menjadi perjudian atau pertaruhan. ${ }^{26}$

Pasal 257 dan Pasal 258 KUHD. Apabila kita melihat ketentuan Pasal 255 KUHD disebutkan "bahwa suatu pertanggungan harus dibuat secara tertulis dalam suatu akta yang dinamakan polis". Di sini dikatakan seolah-olah polis merupakan syarat mutlak untuk terbentuknya perjanjian asuransi. Apabila kita memperhatikan Pasal 257 KUHD sepertinya terjadi kontradiksi dengan Pasal 255 KUHD, sebenarnya tidak demikian. Dalam Pasal 257 KUHD disebutkan bahwa perjanjian asuransi diterbitkan seketika setelah ditutup, hak dan kewajiban timbal balik dari tertanggung dan penanggung mulai berlaku sejak saat itu. Artinya apabila kedua belah pihak telah menutup perjanjian asuransi akan tetapi polisnya belum dibuat, maka tertanggung tetap berhak menuntut ganti rugi apabila peristiwa yang diperjanjikan terjadi. Tertanggung harus membuktikan bahwa perjanjian asuransi telah ditutup dengan alat-alat pembuktian yang lain misalnya surat menyurat antara penanggung dengan tertanggung, catatan penanggung, nota penutupan, dan lain-lain. Pasal 255 KUHD merupakan pasal yang berkaitan dengan pelaksanaan hak dan kewajiban atas pelaksanaan perjanjian asuransi, sedangkan Pasal 257 KUHD merupakan pasal yang berkaitan dengan pembentukan perjanjian asuransi.

Pasal 260 dan 261 KUHD mengatur tentang asuransi yang ditutup dengan perantaraan makelar atau agen. Dari Pasal 260 KUHD diketahui bahwa jika perjanjian asuransi ditutup dengan perantaraan makelar, maka polis yang telah ditandatangani harus diserahkan dalam waktu delapan hari sejak ditandatangan. Pasal 261 KUHD menetapkan bahwa jika terjadi kelalaian dalam hal yang ditetapkan dalam Pasal 259 KUHD dan 260 KUHD, maka penanggung wajib memberikan ganti rugi. Berkaitan dengan hal ini, berdasarkan, apabila terdapat kesalahan broker atau agen asuransi dalam memberikan pelayanan kepada tertanggung, maka agen asuransi dapat dituntut baik secara perdata maupun pidana. Hal ini pernah terjadi bahwa agen asuransi lupa menuliskan bahkan pekerjaan tertanggung memiliki tingkat risiko yang tinggi misalnya pilot, kontraktor, orang yang bekerja di pertambangan, orang yang bekerja di pengeboran minyak dan lain sebagainya. Agen asuransi menuliskan tidak sesuai dengan pernyataan dan informasi yang diberikan tertanggung kepada agen asuransi yang nantinya informasi tersebut

26 Man Suparman, Op. Cit., h. 17. 
akan diberikan kepada penanggung. Hal ini biasanya dilakukan oleh agen asuransi agar supaya premi asuransinya tidak terlalu mahal dikarenakan tingkat risiko pekerjaan dari tertanggung atau pembayar premi yang terlalu tinggi. Apabila memang demikian, hal tersebut dilakukan oleh agen asuransi dengan awalnya dalih supaya preminya tidak terlalu mahal, maka agen asuransi dapat dikenakan sanksi. Terkadang apabila hal ini terjadi agen asuransi pura-pura lupa atau tidak mengetahui bahwa pekerjaan dari tertanggung atau pembayar premi berisiko tinggi, dengan dalih tertanggung atau pembayar premi yang tidak memberikan keterangan yang sebenar-benarnya kepada agen sehingga dikemudian hari apabila tertanggung meninggal, maka ahli waris tidak mendapatkan apa yang sebenarnya menjadi haknya, yaitu uang asuransi yang harusnya dibayar oleh penanggung.

Di dalam KUHD walaupun sudah terdapat pasal-pasal tersebut di atas yang dapat melindungi tertanggung atau pemegang polis dari penanggung yang tidak bertanggung jawab terhadap suatu peristiwa tidak pasti yang terjadi kepada tertanggung.Bahkan dengan adanya Pasal 251 KUHD inilah yang sering digunakan penanggung untuk berlindung dan tidak membayar yang harusnya menjadi kewajibannya.

Selain diatur didalam KUHD, tertanggung selaku konsumen dari perusahaan asuransi juga mendapatkan perlindungan yang diatur dalam Undang-Undang Perlindungan Konsumen Nomor 8 tahun 1999 (UU No. 8/1999). Namun didalamnya lebih banyak mengatur tentang perilaku pelaku usaha, hal ini dipahami karena kerugian yang diderita konsumen seringkali akibat dari pelaku usaha, sehingga perilaku pelaku usaha perlu diatur dan bagi pelanggar dikenakan sanksi yang setimpal.Esensi dari undang-undang ini adalah mengatur perilaku pelaku usaha dengan tujuan agar konsumen terlindungi secara hukum. ${ }^{27}$

Undang-Undang tentang Perlindungan Konsumen tidak hanya mencantumkan hak-hak dan kewajiban-kewajiban dari konsumen, melainkan juga hak-hak dan kewajiban - kewajiban dari pelaku usaha. Adapun hak dan kewajiban yang dimiliki oleh konsumen apabila dihubungkan dengan perjanjian asuransi maka pemegang polis atau tertanggung selaku konsumen seperti yang disebutkan dalam ketentuan Pasal 4 jo Pasal 5 Undang Undang Perlindungan Konsumen. Sedangkan kewajiban tertanggung sebagai konsumen dapat mengacu pada pada Pasal 5 UU No. 8/1999. Namun, kelihatan bahwa hak yang diberikan kepada konsumen yang diatur dalam Pasal 4 UU No. 8/1999 lebih banyak dibandingkan dengan hak pelaku usaha yang dimuat dalam Pasal 6 UU No. 8/1999 dan kewajiban pelaku usaha dalam Pasal 7 UU No. 8/1999 lebih banyak lagi dari kewajiban konsumen yang termuat dalam Pasal 5 UU No. 8/1999.

Hak Penanggung atau Perusahaan Asuransi sebagai Pelaku usaha dapat mengacu pada Pasal 6 UU No. 8/1999 sedangkan kewajiban perusahaan asuransi sebagai pelaku usaha mengacu pada Pasal 7 UU No. 8/1999. Dalam hak dan kewajiban bagi pelaku usaha yang perlu digaris bawahi adalah terkait hak yang dimiliki oleh pelaku usaha untuk mendapatkan perlindungan hukum dari tindakan konsumen yang beritikad tidak baik. Apabila diimplementasikan dalam

27 Johanes Gunawan, Tanggung Jawab Pelaku Usaha menurut Undang-Undang No. 8. Tahun 1999 tentang Perlindungan Konsumen, Bandung: Alumni, 2000, h.5. 
perjanjian asuransi jiwa, penanggung selaku pelaku usaha dapat menolak untuk melakukan kewajibannya untuk membayar uang pertanggungan apabila diketahui bahwa pemegang polis tidak beritikad baik terhadap perjanjian asuransi jiwa tersebut. Namun itikad baik tidak hanya dimiliki oleh pemegang polis saja, penanggung selaku pelaku usaha juga berkewajiban beritikad baik terhadap perjanjian asuransi jiwa. Hal ini bisa ditunjukkan dengan cara penanggung harus menjelaskan secara lengkap dan benar kepada tertanggung mengenai kondisi obyek asuransi.

Selain mengatur hak dan kewajiban pelaku usaha, Undang Undang Perlindungan Konsumen juga juga mengatur perbuatan yang dilarang dilakukan oleh pelaku usaha yang dapat menjadi acuan bagi perusahaan asuransi, antara lain: a) Memperdagangkan jasa asuransi yang tidak sesuai dengan standar yang dipersyaratakan dan ketentuan peraturan perundangundangan, yaitu yang tidak sesuai dengan yang diatur dalam BW, KUHD, dan Undang Undang Usaha Perasuransian; b) Memperdagangkan jasa asuransi yang tidak sesuai dengan janji yang dinyatakan dalam keterangan, iklan dan promosi; c) Menawarkan, mempromosikan, mengiklankan asuransi yang tidak benar; d) Menawarkan, mempromosikan, mengiklankan asuransi yang menyesatkan; e) Menawarkan jasa asuransi dengan cara pemaksaan atau cara lain yang dapat menimbulkan gangguan baik fisik maupun psikis terhadap konsumen; f) Memproduksi iklan yang mengelabui konsumen.

Berkaitan dengan tanggung jawab pelaku usaha kita lihat pada Pasal 19 UU No. 8/1999. Dengan mengacu pada ketentuan Pasal 19 UU No. 8/1999 ini maka perusahaan asuransi bertanggung jawab memberikan ganti rugi atas kerugian yang diderita tertanggung atau pemegang polis. Namun hal ini tidak berlaku apabila perusahaan asuransi dapat membuktikan bahwa kerugian yang diderita oleh pemegang polis merupakan kesalahan dari pemegang polis itu sendiri untuk asuransi kerugian. Pada asuransi jiwa, perusahaan asuransi tetap harus melaksanakan tanggung jawabnya kepada tertanggung atau pemegang polis apabila terjadi peristiwa tidak pasti misalnya kematian, maka perusahaan asuransi harus memberikan santunan atau klaim yang diajukan oleh ahli waris kepada perusahaan asuransi sesuai dengan yang telah disepakati.

Pada Pasal 23 UU No. 8/1999 adalah satu pasal yang tampaknya diselipkan secara spesifik, yang khusus mengatur hak konsumen untuk menggugat pelaku usaha yang menolak, dan/atau tidak memberi tanggapan, dan/atau tidak memenuhi ganti rugi atas tuntutan konsumen sebagaimana dimaksud dalam Pasal 19 UU No. 8/1999, baik melalui badan penyelesaian sengketa konsumen maupun dengan mengajukannya ke badan peradilan di tempat kedudukan konsumen.

Perlindungan konsumen diselenggarakan salah satunya atas dasar asas kepastian hukum. Dengan asas kepastian hukum dini dimaksudkan agar baik pelaku usaha maupun konsumen mentaati hukum dan memperoleh keadilan dalam penyelenggaraan perlindungan konsumen khususnya bagi pemegang polis asuransi jiwa, serta negara menjamin adanya kepastian hukum. Dalam perjanjian asuransi sering dimuat janji-janji khusus yang dirumuskan dengan tegas dalam 
polis, yang lazim disebut klausula asuransi. Maksud klausula tersebut adalah untuk mengetahui batas tanggung jawab penanggung dalam pembayaran ganti kerugian apabila terjadi peristiwa yang menimbulkan kerugian. Untuk itu selain tertanggung harus diberikan perlindungan, penanggung juga harus bertanggung jawab terhadap klaim asuransi yang diajukan oleh ahli waris dalam perjanjian asuransi jiwa. Tanggung jawab penanggung disini dimaksudkan bahwa penanggung selaku pelaku usaha yang menerima pengalihan risiko wajib membayar klaim dari ahli waris atas terjadinya suatu peristiwa tidak pasti yang terjadi, misalnya adanya kematian.

Penulis lebih menekankan dengan istilah tanggung jawab bukan tanggung gugat karena didalam asuransi yang ada setelah pengalihan risiko dari tertanggung kepada penanggung adalah tanggung jawab, bukan tanggung gugat. Di dalam hukum asuransi yang dikenal adalah tanggung jawab perusahaan asuransi atas adanya suatu peristiwa tidak pasti yang terjadi dengan adanya kematian yang sudah diperhitungan dengan adanya pembayaran premi.Penulis tidak menggunakan istilah tanggung gugat karena dirasakan kurang tepat apabila hal tersebut dipergunakan dalam hukum asuransi.

Polis dalam perjanjian asuransi dibuat oleh penanggung yang kemudian diberikan kepada tertanggung. Pembuatan polis oleh penanggung sesuai dengan fungsi polis sebagai bukti tertulis bagi kepentingan tertanggung. Keberadaan polis tidak mutlak tapi penting apabila dikaitkan dengan fungsinya. Tidak adanya polis bukan berarti perjanjian asuransi tidak sah, tapi bisa dituntut pembatalan, karena polis bukan merupakan syarat dalam perjanjian asuransi, tetapi keberadaaannya diwajibkan. Fungsi polis dalam perjanjian asuransi adalah: 1) Sebagai dasar pelaksanaan perjanjian; 2) Sebagai alat bukti tertulis; 3) Sebagai dasar tuntutan apabila terjadi sengketa; 4) Sebagai dasar penghitungan ganti rugi. Oleh karena itu fungsi polis bagi penanggung selaku pihak yang berkewajiban menyerahkan polis kepada tertanggung adalah sebagai bukti tertulis atas jaminan kepada tertanggung untuk membayar ganti rugi atau klaim yang diderita oleh tertanggung, sebagai bukti otentik untuk menolak tuntutan ganti rugi atau klaim yang diajukan tertanggung atau ahli waris apabila klaim yang diajukan tidak sesuai dengan syarat yang tercantum dalam polis.

Fungsi polis bagi tertanggung tentunya merupakan kewajiban bagi penanggung yang harus dipenuhi terhadap tertanggung, yaitu: 1) Sebagai bukti tertulis atas jaminan penanggung untuk mengganti kerugian atau klaim; 2) Sebagai bukti otentik untuk menuntut penanggung apabila lalai atau tidak memenuhi jaminannya. Terkait dengan kewajiban penanggung terhadap polis, maka penanggung wajib menjamin atas kerugian yang diderita tertanggung atas peristiwa tidak pasti yang menimpa tertanggung, membayar klaim kepada tertanggung atau ahli warisnya, dan wajib membuat dan menandatangani polis serta segera meyerahkannya kepada tertanggung.

Asuransi tidak hanya dapat diadakan untuk kepentingan sendiri, tetapi juga untuk kepentingan pihak ketiga, baik berdasarkan kuasa umum atau kuasa khusus, bahkan tanpa pengetahuan pihak ketiga yang berkepentingan.Apabila asuransi tersebut diadakan untuk kepentingan pihak ketiga, maka menurut ketentuan Pasal 265 KUHD, hal itu ditegaskan dalam 
polis apakah terjadi berdasarkan pemberian kuasa atau tanpa pengetahuan pihak ketiga yang berkepentingan. Hal ini dalam praktik di lapangan ditemukan oleh penulis bahwa seseorang dapat mengasuransikan orang lain contohnya keponakannya karena orang tersebut masih terdapat hubungan keluarga, misalnya seorang tante yang mengasuransikan keponakannya karena masih ada hubungan keluarga, walaupun bukan orang tua langsung keponakannya tersebut, penerima manfaat selain orang tua dari tertanggung apabila masih hidup, dapat juga tantenya tersebut sebagai pengganti orang tua apabila orang tua dari ponakannya tersebut telah meninggal dunia.

Dalam perjanjian asuransi yang telah memenuhi syarat umum ataupun khusus dalam arti sah menurut hukum dan tidak terkandung suatu hal yang menyebabkan batalnya perjanjian tidaklah selalu diakhiri dengan pemenuhan kewajiban pembayaran ganti rugi atau klaim oleh penanggung. Setiap peristiwa tidak pasti yang timbul dalam perjanjian asuransi adalah merupakan kewajiban penanggung untuk membayar sejumlah uang yang disebut ganti rugi (verzekerde som) kepada tertanggung, dengan syarat peristiwa tidak pasti yang terjadi tersebut adalah diakibatkan oleh peristiwa tidak pasti (onzeker voorval) yang telah disepakati dan terbukti bahwa tertanggung benar-benar berkepentingan atas kejadian yang terjadi tersebut.

Ada beberapa hal yang harus diperhatikan untuk menentukan apakah penanggung harus memenuhi kewajibannya untuk bertanggung jawab membayar ganti rugi atau tidak antara lain: 1) Bahwa peristiwa tidak pasti yang terjadi secara wajar tidak dapat diharapkan terjadinya meskipun peristiwa tersebut telah diperjanjikan lebih dulu terjadinya; 2) Bahwa kerugian yang terjadi benar-benar diakibatkan oleh peristiwa tidak pasti yang diperjanjikan dalam perjanjian asuransi yang dimuat dalam polis; 3) Penanggung tidak wajib membayar ganti rugi bila kerugian disebabkan oleh cacat/kebusukan barang sendiri (khusus untuk asuransi kerugian yang diatur dalam Pasal 249 KUHD); 4) Penanggung tidak wajib membayar ganti rugi atau klaim apabila kerugian timbul dari kesalahan tertanggung sendiri artinya : seseorang yang mempunyai kesalahan sendiri terhadap timbulnya suatu kerugian apabila seharusnya dia bertindak tapi tidak bertindak (untuk asuransi kerugian). Pada asuransi jiwa penanggung tidak akan membayar klaim kepada ahli waris tertanggung apabila meninggalnya akibat bunuh diri.

\section{Kesimpulan}

Itikad baik dalam perjanjian asuransi yang berkeadilan seharusnya bukan hanya dibebankan kepada pihak tertanggung, namun penanggung juga harus beritikad baik dalam melaksakan perjanjian, sehingga terjadi keseimbangan. Memberikan keterangan yang sejelasjelasnya bukan hanya dibebankan pada pihak tertanggung, penanggung juga harus menjelaskan isi perjanjian, cara klaim, berkas apa saja yang nantinya dibutuhkan untuk proses serta klaim apabila terjadi peristiwa tidak pasti.

Perlindungan terhadap tertanggung dan penanggung selalu atas dasar keadilan. Penanggung harus bertanggung jawab terhadap klaim asuransi yang diajukan oleh tertanggung 
maupun ahli waris yang beritikad baik. Penanggung dilarang menggunakan Pasal 251 KUHD sebagai dasar bagi penanggung untuk menghindari kewajiban membayar klaim yang diajukan oleh tertanggung maupun ahli waris tertanggung.

Pemerintah seharusnya merivisi atau mereview Pasal 251 KUHD karena isi pasal ini dirasakan sangat merugikan tertanggung selaku konsumen perusahaan asuransi, sehingga akan tercipta kenyamanan bagi tertanggung untuk memproteksi dirinya melalui perjanjian asuransi. Dewan Perwakilan Rakyat segera mensyahkan peraturan perjanjian asuransi, terkait dengan Rancangan Undang Undang Perjanjian Asuransi yang telah dibuat.Undang Undang Perlindungan Konsumen hendaknya mengatur lebih spesifik dan lebih lengkap tentang perlindungan bagi pemegang polis sebagai tertanggung (konsumen) sehingga apabila terjadi sengketa antara pemegang polis dengan perusahaan asuransi sehingga tercipta keadilan bagi para pihak yang membuat perjanjian.

\section{Daftar Bacaan}

Buku

Budiono, Herlian,Asas keseimbangan Bagi Hukum Perjanjian Indonesia Hukum Perjanjian Berlandaskan Asas- Asas Wigati Indonesia, Bandung: Citra Aditya Bakti, 2008.

Gunawan,JohanesTanggung Jawab Pelaku Usaha menurut Undang-Undang No. 8. Tahun 1999 tentang Perlindungan Konsumen,Bandung: Mandar Maju, 2000.

Hartono,Sri Rejeki,Asuransi dan Hukum Asuransi, Semarang:IKIP Semarang Press, 2000.

Khairandy,Ridwan,Itikad Baik Dalam Kebebasan Berkontrak, Universitas Indonesia Fakultas Hukum Pascasarjana, 2003.

Sastrawidjaja,M. Suparman,Hukum Asuransi Perlindungan Tertanggung Asuransi Deposito Usaha Perasuransian,Bandung:Alumni, 1993.

\section{Internet}

http://ryaniskandar.wordpress.com/Prinsip -prinsip Dasar Asuransi., diakses pada tanggal 3 Juli 2013. 